\title{
The Effect of Art Education on the Selective Attention Skills and Development of Preschoolers at 4 - 5 Years
}

\author{
Zeynep Cetin', Miray Özözen Danacı ${ }^{2}$ \\ ${ }^{1}$ Faculty of Healthy Sciences, Hacettepe University, Ankara, Turkey \\ ${ }^{2}$ Department of Child Development, Duzce University, Duzce, Turkey \\ Email: zcetin@hacettepe.edu.tr, mirayozozen@hotmail.com
}

Received 17 August 2015; accepted 7 December 2015; published 10 December 2015

Copyright (C) 2015 by authors and Scientific Research Publishing Inc.

This work is licensed under the Creative Commons Attribution International License (CC BY). http://creativecommons.org/licenses/by/4.0/

(c) (i) Open Access

\begin{abstract}
Art allows children to express their feelings and thoughts in a most convenient way, and enhance their intellectual and physical skills. This research discusses mixed-mode art education programs in preschool institutions under the auspices of the Ministry of National Education, and determines their effect on the selective attention skills of 4 - 5 years old children. The research sample included 90 children, male and female, between the ages of four and five years, who were attending preschool institutions under the auspices of the Ministry of National Education in the 2013-2014 academic year. A personal information form concerning demographic data was prepared by the researcher. Quantitative research methods were used. Pre-tests and post-tests were administered to the experimental and control groups. The experimental group was also taught about the pretest. The Frankfurter Test, developed by Raatz and Möhling (1971), was used to measure the children's selective attention levels. Pre-test training for the experimental group included eight sessions. Each training session was $\mathbf{3 0}$ minutes long. The training was four weeks long with two sessions a week. The research found a significant difference between the experimental group and the control group. Art education needs to be included in formal education in order to develop the selective attention skills of 4 - 5 years old children.
\end{abstract}

Keywords

Child, Art Education, Selective Attention

\section{Introduction}

Change and development are essential parts of human history. Life conditions affect this process of change and 
development. The first six years of a child's life is an important period in which children achieve physical, social, emotional and intellectual development. This is a fundamental stage of life. Ari (2003) has demonstrated that the preschool years affect the rest of people's lives: their personality formation, fundamental knowledge, basic facts, skills and abilities. Ari considers this period as one of the most critical periods of life.

Art is often seen as a concept that concerns only famous artists. However, aesthetic values emerge in the early period of life by paying attention to artistic activities. Therefore, art education has an important role in the early childhood. Early childhood art education includes activities which support child development and creativity. A systematic and multifaceted art education program leads to changes in people's conception of the world and the cosmos. It allows them to become more creative, self-confident and productive, ready to realize their potential skills, and also encourages them to affect their social community positively (Ture, 2007).

Artistic activity can be defined as a creative human practice in which one's talent and imagination are used, through the guidance of life experiences, to express thoughts, aims, emotions, situations and events, and to present them to others (Dickie, 2005; Bozkurt, 1995). In early childhood, children display authentic behaviors, make curious discoveries, play with every object that grabs their attention, and use their creativity freely. Hence, artistic emotions and insights began to arise. Since children have not yet internalized projects, prejudices and rules, early childhood is a highly creative period with productive outcomes. Art helps children combine their knowledge of science, social studies, health, mathematics, literature and other domains. Art is also important to individualized education programs (Brewer, 2001; Erkal et al., 1988).

Regarding the effect of art on education, Parker (1988) indicated that children need to learn meaningful things that are related to their daily life, and that education needs to ensure attention and expression as well. Artistic activities require deep insight into the implicit and explanatory meaning of things, rather than their superficial or discursive meaning (Sergiovanni \& Starratt, 1993; Seckin, 1988). Based on research findings, Gardner (1999) considered artistic education as a completely cognitive activity (Zessoules et al., 1993). Effective art education enhances concentration, problem solving skills, self-sufficiency, coordination, attention and self-discipline (Jensen, 2006). Artistic activities may also enhance the attention skills that ensure intellectual balance.

Attention is a fundamental cognitive function that affects our daily life, education and work life. Attention refers to the awareness of stimulants. These stimulants can be internal such as thoughts and memories, or exterior such as visuals and sounds. Many of the exterior stimulants are captured by the sense organs, but only a part of them are selected to be perceived. A human is a finite being with limited sensory capacity, and cannot respond to every stimulant. The brain selects the stimulants to be perceived. These stimulants can relate to a range of variables. Unlike unconscious attention and filtered attention, selective attention focuses on a specific object. Selective perception and perceptive rules are also involved in this process (Onan, 2010; Karaduman, 2004). Time management requires concentration and attention (Lindenbergerne, 2005). Art education leads children to consider details and recognize things they have not yet noticed (Gültekin, 2010).

Children feel the need to improve their skills and engage in artistic activities such as painting, sculpture, music, song, drama, dramatic play and dance, and to learn art concepts. Children's participation in artistic activities is a valuable and meaningful experience (Goldhawk, 1998). Silverstone (1993) indicated that art can be a way of self-expression for people who can divert others' attention by using words effectively. This study explores the impact of "Mixed-Mode Art Education Program" on the attention skills of 4 - 5 years old children.

\section{Methodology}

\subsection{Participants}

The research sample included children, male and female, between the ages of 4 and 5 years who were attending preschool institutions under the auspices of the Ministry of National Education in Duzce.

This research uses an experimental model with a pre-test and post-test. It was conducted according to preliminary knowledge obtained from the children and their level of readiness.

The experimental and control groups, randomly selected, included 90 children. Of them, 40 were 4 years old, and 50 were 5 years old. The four year olds had attended pre-school for a year, and the five year olds had done so for two years.

Taking into consideration the children's family type, their cultural background and economic conditions, experimental and control groups were formed at the same level. A family information form was prepared by the researcher. This form solicits information about the children's age, gender, family type, socio-economic condi- 
tions, cultural background and the duration of their school attendance.

\subsection{Data Collection and Analysis}

The Frankfurter Test was administered as a pre-test and post-test to the experimental group. This test was developed by Raatz and Möhling (1971). To check its reliability, the test-retest method was used. This test was administered to 266 children between the ages of five-six years in 1968, 1170 children between the ages of five and six years in 1970 and 29, four-years olds in 1971 (Kayili \& Ari, 2011). In the test there were apples and pears that resembled each other, and children were asked to find the pears and to mark them. First, a pre-exercise with a single row of figures was administered. It was 90 seconds long, and the instruction was to find the desired figure among a mixed group of figures. Then, a 14-row test with similar instructions was administered to the children. It was eight minutes long. Standard scores, raw scores and the number of errors on the attention test were entered in the SPSS program, which was used for the statistical analysis.

After the pre-test, the "Mixed-Mode Art Education Program," prepared by researcher, became the model and its method was used in the administration of the test to the experimental group. It was a four week training program with two sessions a week. Each training session was 30 minutes long. The first three dimensions were used in the first session of the week, and the remaining third dimension was used in the second session of the week. The program had six dimensions, namely painting studies, kneading clay, design, paper-collage, print and waste material study. Each dimension included five studies (Table 1). After training, Frankfurter Test (1971) was administered again as a post-test.

\section{Results}

According to Table 2, the significance level $P<0.01$ implies that statistically significant difference was not found between experimental and control groups with regard to their mean scores for the pre-tests $(P>0.05)$. Children in the experimental and control groups had the same pre-test (Frankfurter Test) mean score levels. It shows that their attention skills were similar.

Table 3 shows the pre-test and post-test values of the experimental and control groups. The research found that the Frankfurter pre-test mean score for the experimental group was 60.172, while, after training, their post-test mean score was 67.734 . The significance level $P<0.01$ indicates a significant difference between the pre-test and post-test scores of the experiment group. This result shows that art education affects children's attention skills. The art education program had a positive influence on the children's attention skills.

Salderay's study (2014) discusses the importance of artistic activities in private education and indicates that a

Table 1. Mixed-mode art education program for 4 - 5 years olds.

\begin{tabular}{lcl}
\hline \multicolumn{2}{c}{ Dimensions } & \multicolumn{1}{c}{ Studies } \\
\hline 1. & Painting & Hand paint, gouache paint, pastel, finger paint, sugar paint. \\
2. & Kneading Clay & Kneading, clay soil, paper pulp, salt ceramic. \\
3. & Design & Line, figure, tissue, form, color search, shape search. \\
4. & Paper/Collage & Folding (origami), cutting, rolling, using scissors, pasting, tearing. \\
& Print & $\begin{array}{l}\text { Completing cards, sand paint, ironing, pulverization, straw blown watercolors, prints } \\
\text { (potato, brush, sponge, rope, hand, leaf), bottle/decorative painting. }\end{array}$ \\
6. & Waste Material Study & Three dimensional studies, educational toy making. \\
\hline
\end{tabular}

Table 2. The difference between the pre-test mean scores of the experimental group and the control groups.

\begin{tabular}{cccccc}
\hline Groups & N & $\bar{X}$ & S & t & P \\
Experiment & 45 & 60.172 & 10.97 & & -0.423 \\
Control & 45 & 61.283 & 10.35 & & 0.684 \\
\hline
\end{tabular}

${ }^{*} \mathrm{P}<0.01$. 
systematic and purposive visual art education affects child development in multiple ways, and improves their attention skills in particular. Salderay also suggests emphasizing visual art practices in the development of child attention skills in private education. According to Gültekin (2010), artistic activities allow children to focus their emotions on a specific object and concentrate their attention. Eliason and Jenkins (1994) and Miller (1996) claimed that the layout of the art activity space affects children's attention levels and emphasized the relation between artistic activities and attention levels.

Alakus and Mercin (2005) considered children's responses in artistic activities, giving special attention to their feelings and thoughts. Moreover, the Holistic Brain Model argues that artistic talents on the top-right quarter of the brain, and skills that require attention are located in the same area.

Tuna's study (2007) defined art criticism as a reflection on art and an attentive observational process, and claimed that the comparative study of art works, analyzing and discussing their content and meaning, helped improve children's skills in visual perception, attention, interpreting and judging.

Art criticism, as a discipline, allow students to recognize details and appreciate the value of forms and figures they have not noticed, and considers aesthetic perception and artistic activities as suitable activities for enhancing early child development (Tuna, 2007). The studies of Dizdar and Terwiel (2010) showed that artistic activities were more useful for three-four-year olds children since they are less patient than five-six-year olds with activities that require attention. They also emphasized that art education improved children's observation and attention skills. James Hanshumacher (1980) analyzed 36 Ph.D. dissertations and indicated that art education facilitated language education, improved creativity with good attention skills, strengthened reading readiness, helped social development and intellectual achievement, contributed to learning process and helped to develop positive attitudes towards school (Jensen, 2006).

According to Table 4, there is a significant difference, $P<0.01$, between Frankfurter post-test scores of the experimental and control groups. One aspect of educational achievement relates to paying attention and focusing and maintaining the same attention level throughout the required time. Artistic activities are about the production of authentic works which require focusing on certain points. This may help improve children's attention skills. Kehnemuyi (1995) showed a strong relationship between children's artistic activities and intellectual development, noting that even drawings such as scribbling requires the coordination of hand, eyes and brain. Similarly, Webster (1990) emphasized the relation between attention and artistic studies by arguing that artistic creative thinking included not only composition, but also attentive listening and attention analysis. Aydemir (2010) noted that early childhood art education improved various skills, particularly it helped prolong attention span.

\section{Conclusion}

This research found a significant difference between the attention levels of the experimental group, to whom the

Table 3. T-test results for pre-test and post-test mean scores of the experimental and control groups.

\begin{tabular}{cccccccc}
\hline Groups & Tests & N & $\bar{X}$ & S & t & P \\
\hline \multirow{2}{*}{ Experimental Group } & Pre-Test & 45 & 60.172 & 10.97 & -8.765 & 0.000 \\
& Post-Test & 45 & 67.734 & 8.39 & & \\
Control Group & Pre-Test & 45 & 61.283 & 10.35 & -0.413 & 0.052 \\
& Post-Test & 45 & 62.567 & 10.01 & & \\
\hline
\end{tabular}

${ }^{*} P<0.01$.

Table 4. Comparison of the difference between the average scores for the pre-tests of experimental and control groups with importance test.

\begin{tabular}{cccccc}
\hline Groups & $\mathbf{N}$ & $\bar{X}$ & $\mathbf{S}$ & $\mathbf{P}$ & \\
Experiment & 45 & 67.734 & 8.39 & -0.423 \\
Control & 45 & 62.567 & 10.01 & 0.000 \\
\hline
\end{tabular}

${ }^{*} P<0.01$. 
"Mixed-Mode Art Education Program" was administered, and the attention levels of the control group. The post-test results demonstrate the experimental group's higher levels of selective attention and prove the positive effect of Mixed-Mode Art Education Program" on children's attention levels.

Art education improves self-control, self-expression, creative thinking, practical reason, attention skills and attention management. It is very important to initiate art education in the early years of childhood to ensure improved attention skills in children.

Art education should include:

- A focus on the children's interests and abilities and avoiding stereotyping when selecting activities.

- Activities that require high levels of attention such as kneading clay, painting/coloring, paper/collage, prints, three dimensional studies, sculpture/architectural activities, cinema and rhythm.

- To improve children's attention skills, artistic activities need to emphasize the process (method or technique), rather than the outcome (product).

\section{References}

Alakuş, A. O., \& Mercin, L. (2005). The Determination of Methods about Critique, Art Critique and Pedagogical Critique. Journal of Dicle University Faculty of Ziya Gokalp Education, 6, 17-23. http://www.zgefdergi.com/Makaleler/164714972_05_02_Mercin-Alakus.pdf

Ari, M. (2003). The Importance of Early Childhood Education and Quality in Turkey, Development on Early Childhood Term and New Approaches in Education. In M. Sevinç, Ed., Istanbul: Morpa Culture Publishing.

Aydemir, B. (2010). The Museum's Role of on Art Education (p. 23). Master Thesis, Ministry of Culture and Tourism, Fine Arts General Management. http://aregem.kulturturizm.gov.tr/Eklenti/31139,berrakaydemirpdf.pdf?0

Bozkurt, N. (1995). The Institute of Art and Aesthetic (pp. 5-15). Istanbul: Sarmal Publisher.

Brewer, J. A. (2001). Introduction to Early Childhood Education (Chapter 11). USA: Allynand Bacon.

Dickie, G. (2005). The New Institutional Theory of Art. Aesthetics and the Philosophy of Art. The Analytic Tradition. An Anthology içinde. Peter Lamarque and Stein Haugom Olsen (Editörler). Oxford: Blackwell Publishing.

Dizdar, T. C. (2010). The Clay’s Position as a Material on Preschool Art Education (pp. 1-112). Ankara University Rectorate Publishings.

Eliason, C., \& Jenkins, L. (1994). A Practical Guide to Early Childhood Curriculum (pp. 289-294). USA: Merril, an Imprint of Macmillan College Publishing Company.

Erkal, M., Güven, Ö., \& Ayan, D. (1998). The Sports in Sociological Respects (pp. 10-21). Istanbul Der Publishing.

Jensen, E. (2006). The Learning of Brain-Congruent (pp. 98-101). Tra: A. Doganay, Adana: Nobel Publisher.

Gültekin, T. (2010). Child and İntercommunication in the Process of Development of Aesthetic Value on Art Education. International Social Sciences with Peer-Review, E-Journal, 24, 1-14.

http://asosindex.com/journal-article-fulltext?id=17407\&part=1

Goldhawk, S. (1998). Children and the Arts: Making Creative Connections. Washington DC: Arts Education Partnership Council of Chief State School Officers.

Karaduman, B. D. (2004). The Programme of Take Attention's Effect on Fourth and Fifth Class of Student's Taking Attention, Self-Perception and Success Levels (pp. 1-20). Unpublished PhD Thesis, Ankara: Ankara University, Institute of Education Sciences.

Ture, N. (2007). The Contributions of Visual Art Learning as a Tool of Education for Students (pp. 1-55). Master's Thesis, Konya: Selçuk University, Institute of Social Sciences, Güzel Art Education Department. http://acikerisim.selcuk.edu.tr:8080/xmlui/handle/123456789/366

Kayili, G., \& Arı, R. (2011). The Determination of Effect of Montesssori Method Onpreschool Children's Primary School Readiness. Journal of Theory and Practise in Education, Educational Sciences: Theory \& Practice, 11, 2091-2109. https://www.edam.com.tr/kuyeb/pdf/tr/4ceddd3fb92c37d80d3f43a7439b41a3iTAM1.pdf

Kehnemuyi, Z. (1995). The Children's Education of Visual Art. Istanbul: Yap1 Kredi Publishing.

Lindenbergerne, \& Kardos, E. (2005). Zeneterapia Szöveggyüjtemeny. Pecs: Kulcs a Muzsikahoz Kiado.

Parker, H. (1988). The Attention Deficit Disorder Workshop for Parents, Teachers and Kids. Plantation, FL: Impact Publications.

Raatz, U., \& Möhling, R. (1971). Frankfurter tests für Fünfjährige-Konzentration (FTF-K). Weinheim: Beltz.

Salderay, B. (2014). The Transformation of Family Thoughts Scturctures about Visual Art Assesments That Appyly in the Process of Special Education. Journal of Manas Social Researches, 3, 87-101. 
http://journals.manas.edu.kg/mjsr/archives/Y2014_V03_I11/7daa3a2cc6c1b26e62d11b21c7c9415d.pdf

Seckin, N. (1998). A New Approach to Supervision: Supervision of Art, Education Management in Turkey. Edt: H. Taymaz ve M. Hesapçıoglu. Istanbul Culture College Foundation, IE Publishing.

Sergiovanni, T. J., \& Starratt, R. J. (1993). Supervision a Redefinition. New York: Mcgraw-Hill Inc.

Silverstone, L. (1993). Art Therapy the Person Centred Way: Art and the Development of the Person. London: Autonomy Books,

Tuna, S. (2007). The Teaching of Art Criticism in the Primary School in Relation to the Development of Aesthetics Perception and Taste. Ankara University Journal of Faculty of Educational Sciences, 40, 121-133.

Miller, R. (1996). The Developmentally Appropriate Inclusive Classroom in Early Education (pp. 117-140). Albany, NY: Delmar Publishers.

Onan, B. (2010). The Researches about Brain Cognitive Functions and İt's Reflection on Native Language. Tübar-xxvii, 521-561. http://tubar.com.tr/tubar\%20dosya/pdf/2010bahar/onan_bilginer\%20521-561.pdf

Webster, P. R. (1990). Creativity as Creative Thinking. Music Educators Journal (Special Focus), 76, 22-28. http://www.peterrwebster.com/pubs/websterMEJ.pdf http://dx.doi.org/10.2307/3401073

Zessoules, R., Wolf, D. P., \& Gardner, H. (1993). A Better Balance: Arts Propel as an Alternative to Discipline-Based Art Education. Discipline-Based Art Education and Cultural Diversity, Printed in USA. 